\title{
Social Entrepreneurial Intention among Business Undergraduates: An Emerging Economy Perspective ${ }^{1}$
}

\author{
Noorseha Ayob, ${ }^{a^{*}}$ Ching Seng Yap, ${ }^{b}$ Dewi Amat Sapuan, ${ }^{c}$ Md Zabid Abdul Rashid ${ }^{d}$ \\ ${ }^{a}$ Bank Rakyat School of Business and Entrepreneurship, Universiti Tun Abdul Razak, Malaysia \\ bcd Graduate School of Business, Universiti Tun Abdul Razak, Malaysia
}

\begin{abstract}
Social entrepreneurs are viewed as having the abilities to combat social and economic problems in which government, businesses, and non-profits may not be able to solve the problems alone. Consequently, with the collaboration among these sectors, more social enterprises can be established to create social values and development in a nation, specifically among the emerging economies. Therefore, it is timely to investigate what motivates undergraduates to develop social entrepreneurial intention. Drawing from the entrepreneurial models of Shapero and Sokol (1982) and Kruger and Brazeal (1994), this study aims to examine the social entrepreneurial intention among undergraduates from the perspective of an emerging economy. The proposed conceptual model differs from the existing entrepreneurial intention studies by adding the concepts of empathy and social entrepreneurship exposure as the antecedents to perceived desirability and perceived feasibility of social enterprising start-up, which in turn link to social entrepreneurial intention. Using the quota sampling technique, data were collected from 257 business and economics undergraduates from both public and private higher education institutions in Malaysia. The survey instrument was adapted from prior related studies, for instance, Davis (1983) for empathy; Shapero and Sokol (1982) for social entrepreneurship exposure; Krueger (1993) for perceived desirability and perceived feasibility; and Chen et al. (1998) for social entrepreneurial intention. Partial least squares path modelling was used to analyze the hypothesized relationships in the proposed conceptual framework. It is hoped that the findings of this study will shed light on the existing literature of social entrepreneurship, specifically the social entrepreneurial intention studies from the emerging economies perspective.
\end{abstract}

Abstrak: Para wirausahawan sosial dipandang sebagai orang-orang yang memiliki kemampuan untuk memerangi masalah sosial dan ekonomi di dalam bidang pemerintah, bisnis, dan nirlaba yang mungkin tidak dapat memecahkan masalah tersebut sendirian. Dengan kolaborasi antara sektor-sektor ini, dapat dibentuk perusahaan yang lebih sosial untuk menciptakan nilai-nilai sosial dan pembangunan di suatu bangsa, khususnya di antara negara sedang berkembang. Oleh karena itu, merupakan waktu yang tepat untuk meneliti apa yang memotivasi mahasiswa-mahasiswa untuk memiliki niat sosial kewirausahaan. Dari model kewirausahaan Shapero dan Sokol (1982), serta Kruger dan Brazeal (1994), penelitian ini

\section{${ }^{1}$ Acknowledgement}

The project is funded by the Fundamental Research Grant Scheme (FRGS) 2011, Ministry of Higher Education, Malaysia (FRGS/1/11/SS/UNITAR/03/3).

* Corresponding authors. E-mail: noorseha@unirazak.edu.my 
bertujuan untuk menguji niat sosial kewirausahaan di kalangan mahasiswa dari perspektif ekonomi yang muncul. Model konseptual yang diusulkan berbeda dari penelitian atas pemicu niat kewirausahaan yang ada dengan menambahkan konsep empati dan tekanan kewirausahaan sosial untuk memenuhi keinginan dan kelayakan yang diharapkan masyarakat, yang pada gilirannya dapat menghubungkan antara keinginan dan niat kewirausahaan social. Penelitian ini mengunakan teknik quota sampling, data yang dikumpulkan dari 257 pebisnis dan mahasiswa ekonomi dari perguruan tinggi, baik negeri maupun swasta di Malaysia. Instrumen penelitian ini diadaptasi dari studi terkait yang sebelumnya, seperti, Davis (1983) untuk empati, Shapero dan Sokol (1982 ) untuk paparan kewirausahaan sosial; Krueger (1993) untuk keinginan dan kelayakan yang dirasakan, serta Chen et al. (1998) untuk tujuan sosial kewirausahaan. Sebagian yang terkecil dari pemodelan jalur kuadrat digunakan untuk menganalisis hubungan hipotesis dalam kerangka kerja konseptual yang sampaikan. Diharapkan bahwa temuan penelitian ini akan menerangkan literatur yang ada, khususnya tentang sosial kewirausahaan dari perspektif negara-negara sedang berkembang.

Keywords: empathy; Malaysia; social entrepreneurial intention; social enterprises; undergraduates

\section{Introduction}

Social entrepreneurship is a relatively new concept in Malaysia. Social entrepreneurship offers innovative solutions to complex and persistent social issues by applying traditional business and market-oriented models (Dorado 2006; Mair and Noboa 2003; Pearce and Doh 2005; Spear 2006; Brouard and Larivet 2009; Shaker et al. 2009). The main focus is not to optimize profits but also for community building. Social entrepreneurship has gained momentum and the communities around the world are "self-organizing" to directly address issues that affect them. For instance, one of the groundbreaking examples in the world is the Grameen Bank in Bangladesh which has helped millions of poor people especially women to improve their lives and escape poverty by providing them access to financial services. KL Downtown Night Market would be one of the local examples which aims to help ex-drug addicts to obtain employment at its night markets and to offer a support mechanism to help them stay off drugs.
In this connection, there is a pressing need for universities and institutions to adequately prepare marginalized groups to transform their communities by helping to eliminate the oppressive elements of poverty, crime, unemployment and other social ills that have devastated the communities (Prieto 2010). In a developing country like Malaysia, it is sensible that universities should pioneer social entrepreneurship to support the New Economic Model (NEM) that has been introduced by Malaysia Prime Minister (Bernama 2010).

Apart from becoming social entrepreneurs, students who possess social entrepreneurial intentions may be suitable candidates for firms interested in becoming more socially responsible and in engaging social ventures that impact communities (Prieto 2010). Results from a survey distributed to 6,488 Malaysian youths through Facebook, 75 percent of them aspire to be social entrepreneurs who aim for triple bottom line objectives and not profit maximization alone (Sabrie 2010). Even though the survey was not academic oriented, the results were encouraging, and 
more systematic empirical data are required to confirm the findings.

Despite the fact that there has been a steady growth in social entrepreneurship research, little is known about the underlying motivations for social entrepreneurial intention. Various conceptual papers have been published to propose antecedents to social entrepreneurial intention (Mair and Noboa 2003; Tukamushaba et al. 2011). However, there is still lack of empirical data to support the propositions put forth by these studies. Therefore, the study aims to propose a conceptual model that may provide a plausible explanation for social entrepreneurial intention and to test the model through empirical data collected from undergraduates in Malaysia. The conceptual model includes empathy, social entrepreneurship exposure, perceived desirability and perceived feasibility as the antecedents to social entrepreneurial intention. This study is important to shed light on the existing literature of social entrepreneurship, specifically the social entrepreneurial intention studies from the emerging economies perspective.

This paper unfolds as follows: Section two reviews the various social entrepreneurial intention models and prior related empirical studies. Section three describes sampling procedures, the data collection method, and variables and measurement. Section four presents results and discussion. Section five concludes the study and provides implications, limitations and recommendations for future research.

\section{Theoretical Background and Conceptual Framework}

Research on entrepreneurial intention has been ongoing for several years. This re- search has reflected an important effort to monitor attitudes and intentions of students towards starting up their own businesses (Ghulam 2010). The entrepreneurial intention can be defined as a conscious awareness and conviction by an individual that they intend to set up a new business venture and plans to do so in the future (Bird 1988; Thompson 2009). Two main entrepreneurial intention models have emerged in the literature as the main theory-driver models: the theory of planned behavior (Ajzen 1991) and the entrepreneurial event theory (Shapero and Sokol 1982). They have been widely adopted by entrepreneurial intention research to analyze new venture creation. In this sense, one of the most important attempts to integrate both of them is the model of entrepreneurial potential by Krueger and Brazeal (1994).

\section{Theory of Planned Behavior (Ajzen 1991)}

The theory of Planned Behavior revolves around one's intention to act upon behavior (Ajzen 1991). The intention formation is influenced by three factors namely attitude toward the behavior, subjective norm and perceived behavioral control (Ajzen 1991). All of these factors represent people's actual control over their behavior. If one has the required opportunities and resources, and intends to perform the behavior, one should succeed in doing so (Ajzen 1991). Attitude toward behavior refers to an individual's assessment of the behavior whether or not it is favorable. It is determined through an assessment of one's beliefs regarding the consequences arising from behavior and an evaluation of the desirability of these consequences. It is assumed to have two components which work together: beliefs about consequences of the behavior and the corresponding positive or negative judgments 
about each of these features of the behavior. Subjective norm is the perception of the community related to individual about performing the behavior. Krueger et al. (2000) included this measure in their entrepreneurial intentions model but subsequently did not find a relationship between an individual's subjective norm and intention to start a business, calling for more studies with more reliable measures in this research domain. The contribution of the opinion of any given referent is weighted by the motivation that an individual has to comply with the wishes of that referent. Perceived behavioral control refers to the perception of feasibility in performing the behavior. As The Theory of Planned Behavior is an extension of the Theory of Reasoned Action (Fishbein and Ajzen 1975), perceived behavioral control was added to account for situations where non-motivational factors play a role in attitude turning into action (e.g., lack of finan- cial resources may alter perceived behavioral control turning into intention if the behavior was, for example, to purchase a car). Other examples of inhibiting factors might be lack of time, lack of knowledge and skills, and lack of cooperation from others. Perceived behavioral control has also been referred to as feasibility, in particular in studies measuring entrepreneurial intention (Krueger and Brazeal 1994; Krueger et al. 2000; Peterman and Kennedy 2003). Furthermore, Ajzen (2001) stated that perceived behavioral controllability, whilst similar, can be seen as distinct from perceived self-efficacy and that the latter may be a more important antecedent of intentions and actions. In 2002, Ajzen clarified the concept of behavioral control further and highlighted the importance of incorporating self-efficacy and controllability items into intention measures to improve behavior prediction. The Theory of Planned Behavior is depicted in Figure 1.

\section{Figure 1. The Theory of Planned Behavior}

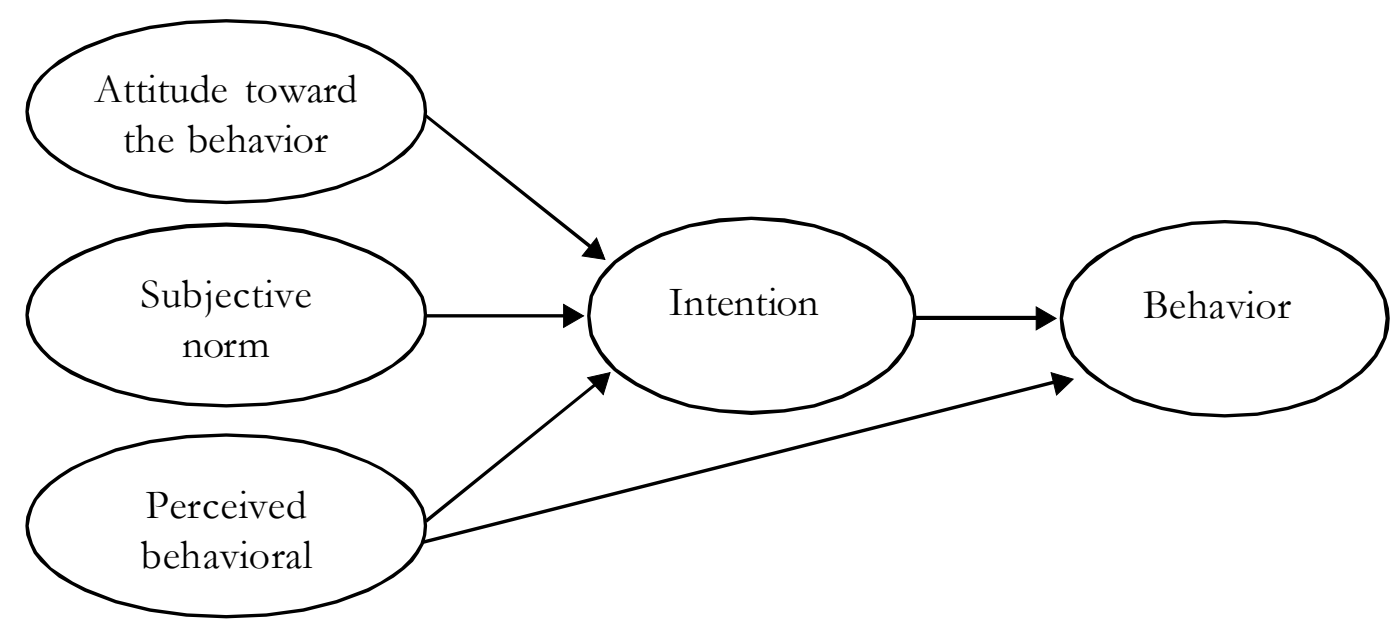

Source: Ajzen (1991) 


\section{Entrepreneurial Event Model (Shapero and Sokol 1982)}

Entrepreneurial Event Model by Shapero and Sokol (1982) is an early intention model focusing on the entrepreneurship field (Singh et al. 2012; Krueger et al. 2000). The model consists of three elements, namely displacement, perceived desirability, and perceived feasibility which ultimately form the intention. According to Shapero and Sokol (1982), displacement is the triggering point that precipitates change in behavior. Displacement can be in negative form such as lack of job satisfaction or in positive form such as getting rewards. An individual will make decision by scanning and assessing the best opportunity based on how he or she perceives desirable and feasible behavior (Shook et al. 2003). Together with propensity to act, intention will be formed especially when the opportunity appears (Nabi et al. 2010). Unfortunately, empirical studies of these specific push and pull factors are limited with results offering little predictive ability (Krueger et al. 2000) and logically, displacement may cause other behaviors than selfemployment.

The second element, perceived desirability, is defined as how an individual finds the attractiveness of starting an entrepreneurial venture (Shapero and Sokol 1982). The perception is affected by personal attitude, values and feelings resulted from one's social environments such as family, education background and surrounding community (Shapero and Sokol 1982). This is further elaborated by Prabhu (1999) whereby those who come from social entrepreneurial oriented communities and families would have bigger potential to become social entrepreneur. Furthermore, Bird (1988) considered desirability to be formed through 'intuitive thinking' in the intentions process, and feasibility, discussed next, as 'rational thinking'. Perceived desirability of entrepreneurship is an affective attitudinal judgment (an emotive response) and entrepreneurs use such judgment to make decisions on whether or not to act (Mitchell et al. 2002). It follows that a goal of entrepreneurship education would be to develop in students, a positive attitude towards entrepreneurship.

The third element, perceived feasibility, on the other hand, is how an individual believes in his or her capability of starting entrepreneurial venture (Shapero and Sokol 1982). This is influenced by one's perception of the available resources such as financial, human resource, and related knowledge (Shapero and Sokol 1982). Shapero and Sokol (1982) make the point that both perceptions and feasibility and desirability necessarily interact. That is, if an individual sees the formation of a new business as unfeasible they may conclude it as undesirable and vice versa. It is therefore possible that students' attitude toward self-employment may be positively impacted by participation in entrepreneurship education. However, in the absence of perceptions of feasibility (belief in one's ability to be selfemployed, and or the ability to acquire necessary resources), self employment intentions may not eventuate. Conversely, even if students' perceptions of feasibility may be positively impacted by participation in entrepreneurship education, self-employment would still not be formed without having a desire to be self-employed.

\section{Entrepreneurial Potential Model (Krueger and Brazeal 1994)}

Krueger and Brazeal (1994) introduced the Entrepreneurial Potential Model which integrates the concepts in Entrepreneurial 
Event Model by Shapero and Sokol (1982) and the Theory of Planned Behavior by Ajzen (1991). It is believed that people venture into entrepreneurship as a result of planned behavior indicated by intention (Krueger and Brazeal 1994; Krueger et al. 2000). Hence these models represent entrepreneurship by showing that intention which is highly influenced by attitudes and that beliefs guides the focus to the favorable behavior, and these attitudes and beliefs are based on perception derived from the surrounding environment (Krueger and Brazeal 1994). The Entrepreneurial Potential Model simplifies the previous models by matching up the perceived desirability to attitude toward behavior and subjective norm, and perceived feasibility to perceived behavioral control (Krueger and Brazeal 1994). Attitude toward behavior and subjective norm correspond to each other in which personal perception of the behavior is also influenced by perception of other people who are close to him or her.

Personal perception of the behavior may differ from how the family members perceived it. Motivation, again, is a key element to reach to their expectation. Krueger and Brazeal (1994) assimilate the concept of selfefficacy into perceived feasibility. Self-efficacy has been determined to be predominant consideration in career selection which entrepreneurship can be one of the options (Bandura et al. 2001). Krueger (1993) cites persuasive evidence that perceived credibility, perceived desirability and propensity to act explain over half the variance in intentions towards entrepreneurship, with feasibility perceptions being the most influential. The Entrepreneurial Potential Model is depicted in Figure 2.

\section{Figure 2. Entrepreneurial Potential Model}

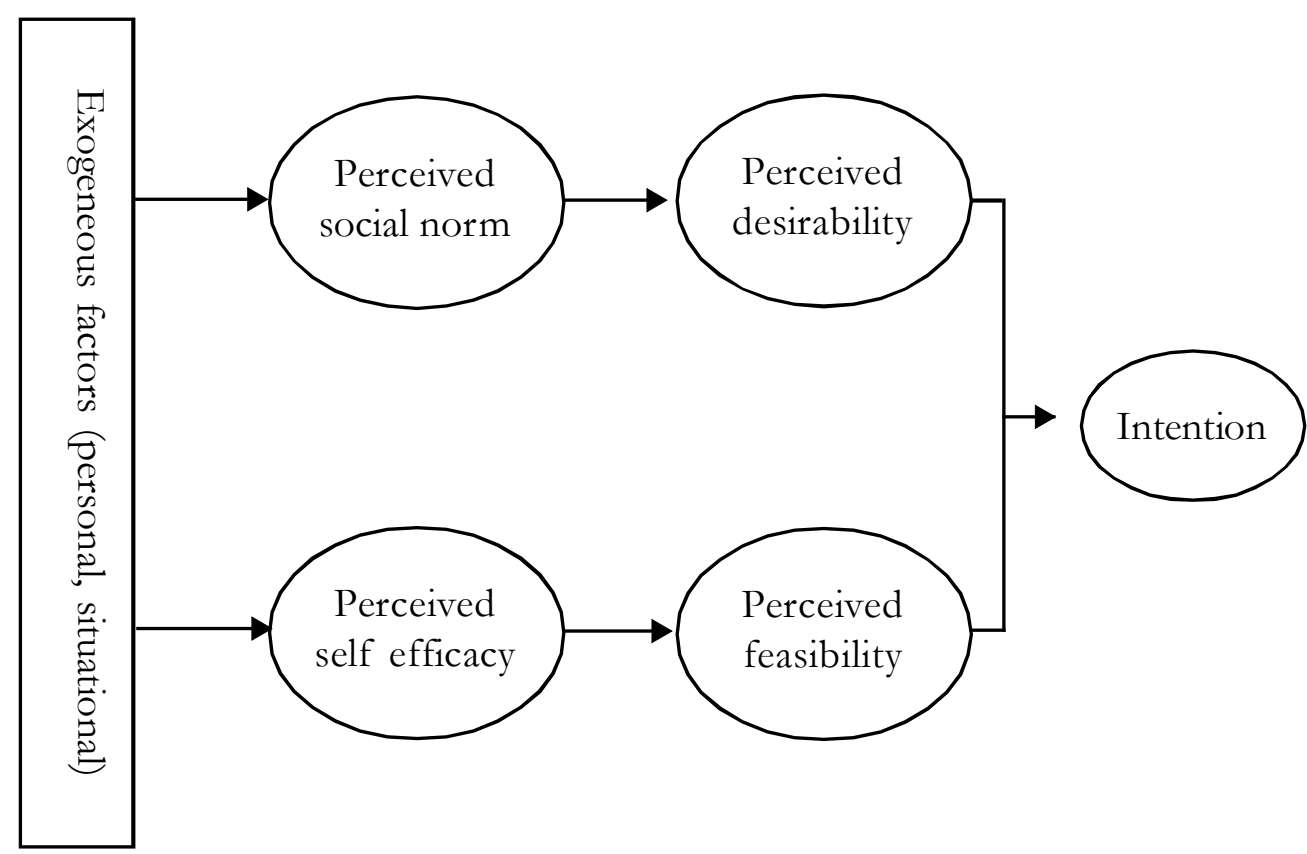

Adapted from Shapero and Sokol (1982); Krueger (1993); Krueger and Brazeal (1994); and Krueger et al. (2000). 


\section{Prior Empirical Studies}

In Malaysia, a number of studies have been conducted to determine the entrepreneurial intention among Malaysian undergraduates. Although in context, social entrepreneurship is different from business entrepreneurship (Mair and Noboa 2003); these studies can be used as preliminary indication to gauge the inclination of the students towards entrepreneurship in general. The study by Zahariah et al. (2010) found that majority of business students have the intention to embark on entrepreneurship and they are mainly influenced by education received and business activities carried out by family members and academics. Personality traits have also been studied as variables to determine students' entrepreneurial intention. Based on the Big Five personality traits, extraversion and openness showed strong relationship with students' entrepreneurial intention, but not neuroticism, agreeableness and conscientiousness (Ismail et al. 2009).

The results show a significant relationship between personality trait and entrepreneurship intention which is consistent to Ismail et al (2009). The respondents showed significant relation between personality traits and intention to become entrepreneurs. Other variables are interest toward becoming entrepreneurs and economic trait. Empathy is known as part of the personality traits (Stueber 2008) which can be a key distinguisher between social entrepreneurs from for-profit entrepreneurs (Mair and Noboa 2003). Empathy has a broad definition in literature and is generally defined as sharing and recognizing the same feelings experienced by other people (Decety and Jackson 2004). Regardless of emotional empathy or cognitive empathy, both are instrumental in affecting perceived desirability par- ticularly in the context of helping behavior (Mair and Noboa 2003). On the same note, McDonald and Messinger (2010) stress the importance of empathy to drive the behavior to assist people in need.

Emotional empathy is vicarious sharing of other's feeling (Smith 2006; McDonald and Messinger 2010) while cognitive empathy is the ability to precisely visualize other's experience or "mental perspective taking" (Smith 2006; McDonald and Messinger 2010). Both emotional and cognitive empathy complement each other in which emotional empathy drives prosocial motivation and cognitive empathy provides prosocial vision (Smith 2006). Together they become a complete element to influence an individual's perceived desirability leading to prosocial oriented behavior.

Exposure, also known in psychology as mere exposure, has an effect on the perception (Zajonc 1968). As such, this study argues that exposure plays an important part as the antecedent to perception of desirability and feasibility. Basu and Virick (2008) categorize the exposure to education, family and direct experience to be influential in entrepreneurial intention formation. Many prior studies agree that education enhances the intention to become entrepreneur. Prabhu (1999) notes that the social work education give people the overviews on social dynamics. The offering of social entrepreneurial courses by top universities and institutions especially in the USA and Europe are evidence of growing interest of the public to receive "educational exposure" on social entrepreneurship (Brock and Steiner 2009). In the local context, Malaysian students who enrolled in an entrepreneurship course showed a positive relationship with the intention to become entrepreneurs (Ismail et al. 2009; Zahariah et al. 2010). In addition, Ooi et al. 
(2011) also identified that universities must be able to design and/or develop the curriculum that would fulfill the students' demands and the industry as the exposure to entrepreneurial courses would certainly, to some extent, influence students' inclination towards entrepreneurship.

Exposure to family business is also a prevalent factor. A social entrepreneur leader may be influenced by family background (Prabhu 1999). Exposure to family business is found to be positively related to entrepreneurial intention, such as entrepreneurship self-efficacy, perception of family support, and business start-up (Carr and Sequeira 2007). Entrepreneurial intention of Malaysian students is also found to be influenced by family business background (Zahariah et al. 2010; Keat et al. 2011).

Direct experience has unique effect on social entrepreneurship. In for-profit entrepreneurship context, the intention is formed from previous experience of starting up business venture (Basu and Virick 2008). Previous working experience also forms a significant relation, especially in the entrepreneurial oriented organization (Keat et al. 2011; Kuehn 2008). While the prior working experience may have the same effect on social entrepreneurs, distinctiveness of social entrepreneurs could be the one that encourages social awareness. Scheiber (2012) in the study of social entrepreneurship in Rio de Janeiro found the respondents who are social entrepreneurs have one or more direct socioeconomic experience such as disparity in society, interaction with people negatively affected by social problem, activities related to volunteering, religious, and social and political activism. By becoming social entrepreneurs, they wish to deal with the social issues and benefit the society (Scheiber 2012).

Based on the above review, this study proposes empathy and exposure to be the antecedents to both perceived desirability and perceived feasibility which in turn affect social entrepreneurial intention.

\section{Proposed Conceptual Framework}

Determining the social entrepreneurship intention among Malaysian undergraduates would set a new horizon to the entrepreneurship landscape locally. As such, the proposed conceptual framework can be used to provide insight on the significant factors that lead to the intention formation. The proposed conceptual framework is adapted from the previous models established by Shapero and Sokol (1982) and Kruger and Brazeal (1994). Empathy and social entrepreneurship exposure are added as the antecedents to both perceived desirability and perceived feasibility, which in turn affect social entrepreneurial intention among undergraduates. The proposed conceptual framework is depicted in Figure 3. 
Figure 3. Proposed Conceptual Framework

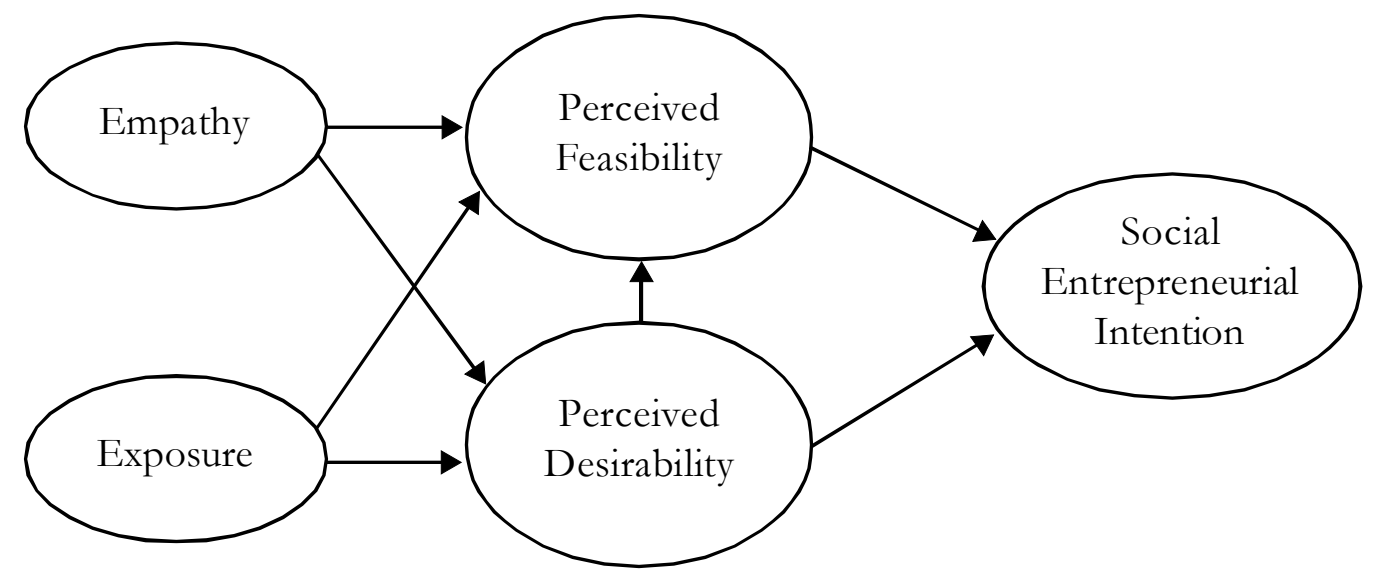

\section{Research Hypotheses}

$H_{1 a}: A$ positive relationship exists between empathy and perceived feasibility of establishing social enterprises.

$H_{1 a}: A$ positive relationship exists between empathy and perceived feasibility of establishing social enterprises.

$H_{16}: A$ positive relationship exists between empathy and perceived desirability of establishing social enterprises.

$H_{2 a}: A$ positive relationship exists between exposure and perceived feasibility of establishing social enterprises.

$H_{2 b}:$ A positive relationship exists between exposure and perceived desirability of establishing social enterprises.

$H_{3}:$ A positive relationship exists between perceived feasibility and perceived desirability of establishing social enterprises.

$H_{4}$ : A positive relationship exists between perceived feasibility and intention to establish social enterprises.

$H_{5}:$ A positive relationship exists between perceived desirability and intention to establish social enterprises.

\section{Methods}

\section{Sample and Sampling Procedures}

The study population consists of business and economics undergraduates in $\mathrm{Ma}$ laysia. As it is difficult to obtain the complete list of students from universities, this study adopted the quota sampling technique using the types of university as the quota sampling criteria. To ensure the samples have the basic knowledge of social entrepreneurship, we selected the universities that offer social entrepreneurship as a separate course to their students. A search from the Malaysian university websites, only four universities offered the course of social entrepreneurship which are Universiti Teknologi MARA Shah Alam Campus and Universiti Malaysia Kelantan (public) and Universiti Tun Abdul Razak and Binary University of Management and Entrepreneurship (private). Four-hundred questionnaire forms were equally distributed to business and economic undergraduates of the four universities. Two hundred and fifty seven respondents returned usable questionnaires, giving a response rate of 64.3 percent, which is considered acceptable. Of the 257 
responses, 130 respondents $(50.6 \%)$ are from the public universities and 127 from the private universities. About two thirds of the respondents are female, similar to that of the student population in Malaysian universities. Business and commerce students constituted the largest portion of the respondents $(26.0 \%)$, followed by marketing $(22.6 \%)$ and economics $(22.0 \%)$. The remaining 30 per- cent of the respondents are from HRM, accounting, entrepreneurship, and finance stream. In terms of their family income, slightly more than three quarters of them are earning below RM5,000 per month. Meanwhile, two thirds have experienced taking entrepreneurship course in their university studies. The detail demographic information is presented in Table 1.

Table 1. Sample Characteristics $(n=257)$

\begin{tabular}{|c|c|c|}
\hline Variable & Frequency & Percentage \\
\hline \multicolumn{3}{|l|}{ Gender } \\
\hline Male & 86 & 33.5 \\
\hline Female & 171 & 66.5 \\
\hline \multicolumn{3}{|l|}{ Program } \\
\hline Business/Commerce & 67 & 26.0 \\
\hline Marketing & 58 & 22.6 \\
\hline Economics & 57 & 22.2 \\
\hline HRM & 34 & 13.2 \\
\hline Accounting & 27 & 10.5 \\
\hline Entrepreneurship & 10 & 3.9 \\
\hline Finance & 4 & 1.6 \\
\hline \multicolumn{3}{|l|}{ Type of University } \\
\hline Public University & 130 & 50.6 \\
\hline Private University & 127 & 49.4 \\
\hline \multicolumn{3}{|l|}{ Monthly Family Income } \\
\hline RM3,000 and below & 142 & 55.3 \\
\hline RM3,001 to RM5,000 & 57 & 22.2 \\
\hline RM5,001 to RM10,000 & 40 & 15.6 \\
\hline Above RM10,000 & 18 & 7.0 \\
\hline \multicolumn{3}{|l|}{ Entrepreneurship Course } \\
\hline Yes & 170 & 66.1 \\
\hline No & 87 & 33.9 \\
\hline
\end{tabular}




\section{Variables and Measurement}

The study adopts the perceptual measures for all the five constructs from prior related studies which show high reliability and validity. The measures for empathy construct were adopted from Davis (1983), which comprises four distinct and independent dimensions: fantasy, perspective taking, emphatic concern, and personal distress. Each dimension is measured by 7-item using 5-point scale from 0 - does not describe me well to 4 describe me very well. The measures for social entrepreneurial exposure construct were modified from Shapero and Sokol's (1982) study on entrepreneurial exposure. Four items on whether the respondents are exposed and involved in social business, as well as their parents, friends, and anyone else they know.
The measures for perceived desirability and feasibility of setting up social enterprise were adopted from Krueger (1993) and were measured by 3-item and 5-item respectively using semantic differential scale. The desirability items include the feeling toward doing the job (love-hate), how tense would be doing the job (very tense-not tense at all), and how enthusiastic would be doing the job (very enthusiastic-very unenthusiastic). The feasibility items include hardness, certainty of success, overwork, knowledge, and confidence about oneself concerning setting up of social enterprise. The social entrepreneurial intention was measured using 4-item in terms of their interest, preparedness, consideration, and attempts to setting up social enterprise. Additional item on how soon they would like to launch the social enterprise was also added.

Table 2. Descriptive Analysis of All Variables

\begin{tabular}{lrrrrrc}
\hline \multicolumn{1}{c}{ Variable } & $\boldsymbol{\alpha}$ & $\mathbf{C R}$ & Min & Max & M & SD \\
\hline Empathy \# & 0.74 & 0.77 & 1.56 & 3.63 & 2.74 & 0.39 \\
Social Entrepreneurial Exposure & - & - & 0.00 & 4.00 & 1.81 & 1.41 \\
Perceived Desirability & 0.70 & 0.87 & 1.00 & 5.00 & 3.73 & 0.92 \\
Perceived Feasibility & 0.63 & 0.80 & 1.33 & 5.00 & 3.44 & 0.69 \\
Social Entrepreneurial Intention & 0.83 & 0.89 & 1.00 & 5.00 & 3.32 & 0.76 \\
\hline
\end{tabular}

Note: $\alpha=$ Cronbach's Alpha; CR= Composite Reliability; \# Empathy scale ranges from 0 to 4, whereas perceived desirability, perceived feasibility and social entrepreneurial intention range from 1 to 5.

Table 3: Correlation Matrix

\begin{tabular}{lcccc}
\hline \multicolumn{1}{c}{ Variable } & $\mathbf{1 .}$ & $\mathbf{2 .}$ & $\mathbf{3 .}$ & $\mathbf{4 .}$ \\
\hline 1. Empathy & - & & & \\
2. Social Entrepreneurial Exposure & $0.17^{* *}$ & - & & \\
3. Perceived Desirability & $0.14^{*}$ & $0.17^{* *}$ & - & \\
4. Perceived Feasibility & $0.26^{* *}$ & 0.12 & $0.52^{* *}$ & \\
5. Social Entrepreneurial Intention & $0.22^{* *}$ & $0.27^{* *}$ & $0.31 * *$ & $0.50 * *$ \\
\hline
\end{tabular}


These items were modified from Chen et al. (1998) who measured entrepreneurial intention to start up a business. Demographic questions were also included to gauge the information about gender, age, family income, program of study, and experience of attending entrepreneurship course.

\section{Results and Discussion}

Means, minimum, maximum, standard deviations, and reliability score using Cronbach's alpha and composite reliability for all constructs under investigation are presented in Table 2 and correlation coefficients between constructs are shown in Table 3. All measures exhibit good Cronbach's alpha which exceeds 0.70 , with the exception of perceived feasibility with the score of 0.63 ; while composite reliability score for all constructs exceed 0.70 . For validity test, all factor loadings of each construct are used to compare with cross factor loadings of other constructs. The analysis shows that the loadings for each construct are loaded higher on their own construct than on other constructs in the model, signifying adequate validity.

Partial least squares path modelling using SmartPLS $2.0 \mathrm{M} 3$ was employed to test the hypothesized relationship in the proposed conceptual framework. As shown in Figure 4 and Table 4, the relationships between perceived desirability and social entrepreneurial intention $(\beta=0.28 ; t=4.69)$, perceived feasibility and perceived desirability $(\beta=0.51$; $t=10.47$ ), social entrepreneurial exposure and perceived desirability $(\beta=0.11 ; t=2.07)$, and empathy and feasibility $(\beta=0.34 ; t=6.71)$ are all positively significant. On the other hand, the relationships between empathy and perceived desirability $(\beta=0.02 ; t=0.59)$, social entrepreneurial exposure and perceived feasibility ( $\beta=0.06 ; t=1.02)$, and perceived feasibility and social entrepreneurial intention $(\beta=0.09 ; t=1.07)$ are not statistically significant. The proportion of variance explained by the model is merely 11.4 percent $\left(\mathrm{R}^{2}=\right.$ 0.114 ).

However, further analysis reveals that perceived desirability fully mediates perceived feasibility and social entrepreneurial intention relationship, perceived feasibility of setting up social enterprise fully mediates empathy and perceived desirability relationship, and perceived feasibility of setting up social enterprise partially mediates exposure and perceived desirability relationship in the proposed framework. Based on Baron and Kenny's (1986) test, mediation is suggested if three conditions are met: (i) the independent variable significantly relates to both mediator and dependent variable, (ii) the mediator significantly relates to the dependent variable, (iii) the effect of the independent variable on the dependent variable is reduced when mediator is included in the regression model. Full mediation is suggested if the independent variable ceased to have any significant effect on the dependent variable when mediator is added, and partial mediation is concluded when the effect of independent variable is reduced but remains statistically significant upon controlling for the mediator.

The mediation analysis shows that perceived feasibility is significantly and positively related to social entrepreneurial intention $(b=0.25, t=3.778)$ and perceived desirability $(b=0.69, t=9.733)$. Similarly, perceived desirability is also significantly and positively related to social entrepreneurial intention $(b=0.26, t=5.249)$. The unstandardized coefficient for perceived feasibility-social entrepreneurial intention is reduced from signifi- 
cant $(b=0.25, t=3.778)$ to nonsignificant $(b=0.10, t=1.336)$. The full mediation of perceived desirability on the relationship between perceived feasibility and social entrepreneurial intention is indicated.

Similar mediation test was applied to perceived feasibility. The analysis shows that empathy is significantly and positively related to perceived desirability $(b=0.34, t=2.327$ ) and perceived feasibility ( $b=0.47, t=4.352$ ). Also, perceived feasibility is significantly and positively related to perceived desirability $(b=0.69, t=9.733)$. The unstandardized coefficient for empathy-perceived desirability is reduced from significant $(b=0.34, t=2.327)$ to nonsignificant $(b=0.02, t=0.143)$. The full mediation of feasibility on the relationship between empathy and perceived desirability is revealed. On the other hand, the unstandardized coefficient for exposure-perceived desirability is reduced from $b=0.11$, $t=2.822$ to $b=0.07, t=2.138$ when perceived feasibility is added to the model; both values remain statistically significant. The analysis shows that perceived feasibility only partially mediate the relationship between exposure and perceived desirability.

In addition to Baron and Kenny test, the Sobel (1982) test is computed to examine the statistical significance of indirect effect. As shown in Tables $5 \mathrm{a}$ and $5 \mathrm{~b}$, the Sobel $\mathrm{Z}$ score of perceived feasibility and empathy stands at 3.519 and 3.926 respectively, both are significant at $p<.001$. Nevertheless, as shown in Table $5 c$, the Sobel Z score of perceived feasibility on exposure-perceived desirability is 1.846 , which is not statistically significant.

Figure 4. Results of the Proposed Conceptual Framework

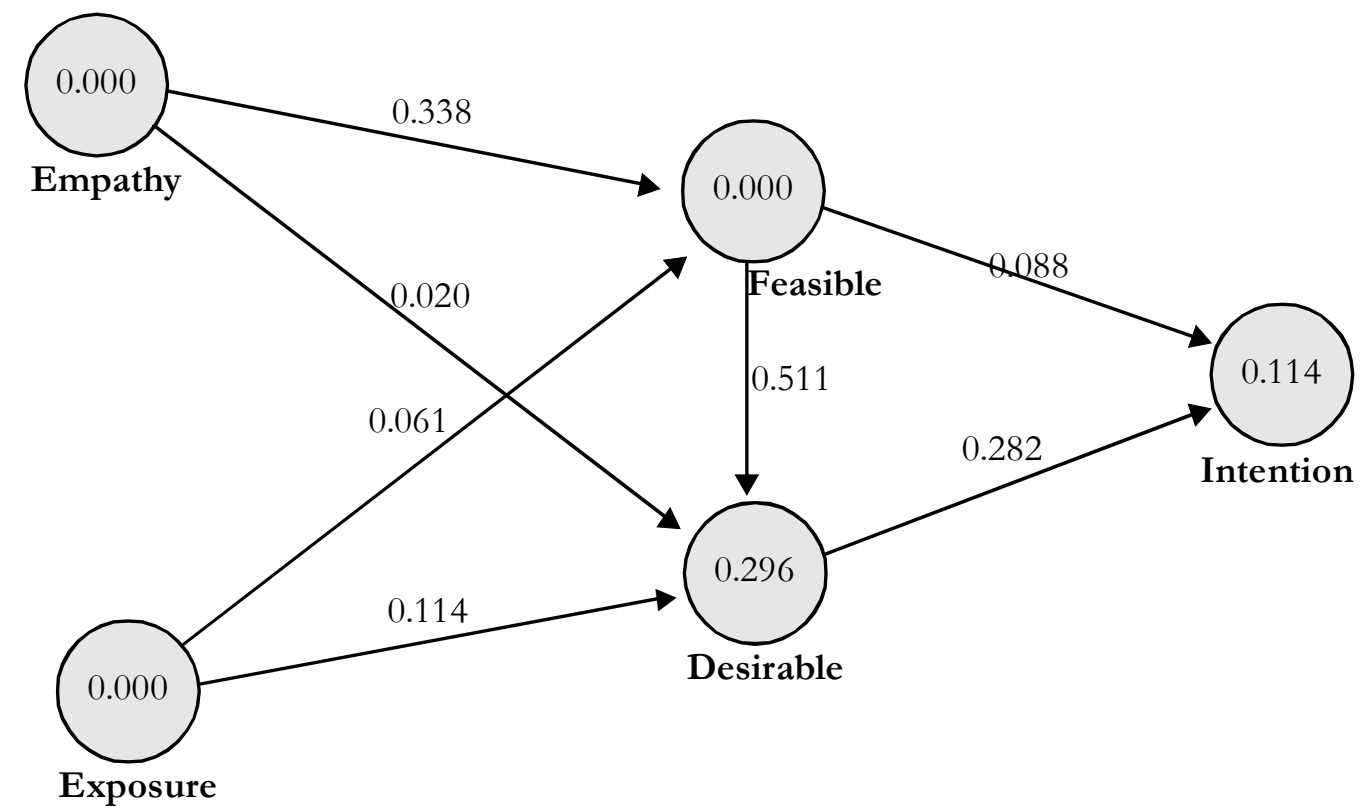


Table 4. Summary of Hypothesis Tests

\begin{tabular}{lcll}
\hline \multicolumn{1}{c}{ Hypothesis } & $\boldsymbol{\beta}$ & $\boldsymbol{t}$ & \multicolumn{1}{c}{ Result } \\
\hline $\mathrm{H}_{1 \mathrm{a}}$. Empathy - Feasibility & 0.34 & $6.71 * *$ & Supported \\
$\mathrm{H}_{1 \mathrm{~b}}$. Empathy - Desirability & 0.02 & 0.59 & Not Supported \\
$\mathrm{H}_{2 \mathrm{a}}$ : Exposure - Feasibility & 0.06 & 1.02 & Not Supported \\
$\mathrm{H}_{2 \mathrm{~b}}$. Exposure - Desirability & 0.11 & $2.07 *$ & Supported \\
$\mathrm{H}_{3}$. Feasibility - Desirability & 0.51 & $10.47 * *$ & Supported \\
$\mathrm{H}_{4}$. Feasibility - Intention & 0.09 & 1.07 & Not Supported \\
$\mathrm{H}_{5}$. Desirability - Intention & 0.28 & $4.69 * *$ & Supported \\
\hline
\end{tabular}

Note: ${ }^{*} p<.05 ; * * p<0.01$

Table 5a. Mediating Effect of Perceived Desirability on Perceived Feasibility-Intention Relationship

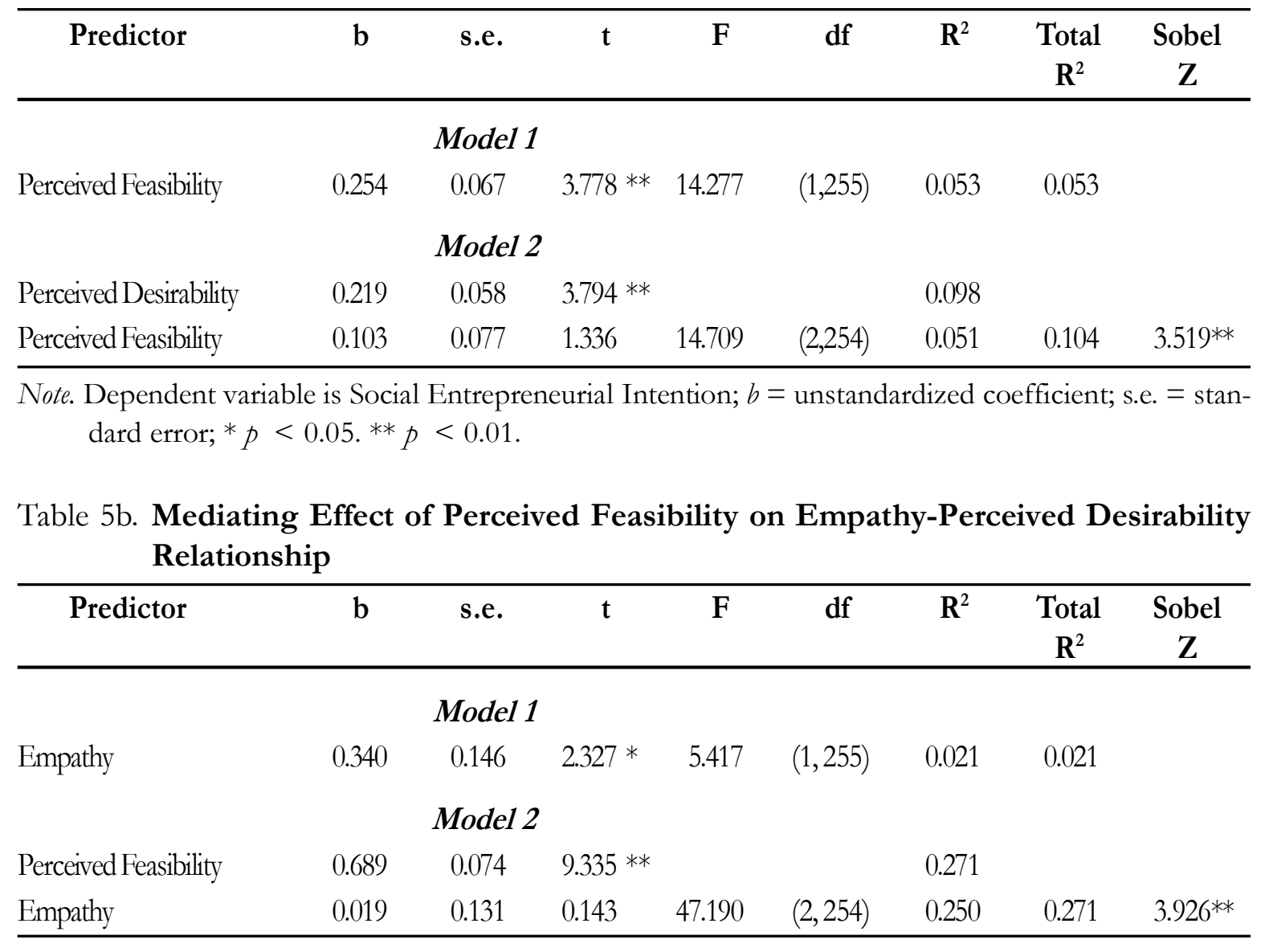

Note: Dependent variable is Perceived Desirability; $b=$ unstandardized coefficient; s.e. $=$ standard error; $* p<0.05 ; * * p<0.01$. 
Table 5c. Mediating Effect of Perceived Feasibility on Exposure-Perceived Desirability Relationship

\begin{tabular}{|c|c|c|c|c|c|c|c|c|}
\hline Predictor & b & s.e. & $\mathrm{t}$ & $\mathrm{F}$ & df & $\mathbf{R}^{2}$ & $\begin{array}{c}\text { Total } \\
\mathbf{R}^{2}\end{array}$ & $\begin{array}{c}\text { Sobel } \\
\text { Z }\end{array}$ \\
\hline & & Model & & & & & & \\
\hline \multirow[t]{2}{*}{ Exposure } & 0.113 & 0.040 & $2.822 *$ & 7.963 & $(1,255)$ & 0.030 & 0.030 & \\
\hline & & Model & & & & & & \\
\hline Perceived Feasibility & 0.674 & 0.071 & $9.481 * *$ & & & 0.271 & & \\
\hline Exposure & 0.074 & 0.035 & $2.138 *$ & 30.352 & $(2,254)$ & 0.250 & 0.284 & 1.846 \\
\hline
\end{tabular}

Note: Dependent variable is Perceived Desirability; $b=$ unstandardized coefficient; s.e. = standard error; $* p<0.05 ; * * p<0.01$.

\section{Conclusion}

\section{Summary of Major Findings}

In sum, the students surveyed generally responded positively toward the constructs under investigation, including the intention to establish social enterprises. The study found that student exposure in social entrepreneurship and their perceived feasibility are both linked positively to perceived desirability to start social entrepreneurship projects, which in turn, leads to their intention to establish social enterprises. In addition, empathy is a significant determinant to perceived feasibility of setting up social enterprise. Perceived desirability also mediates the relationship between perceived feasibility and intention to establish social enterprise.

\section{Significance of the Study}

The study generates important preliminary findings for both social entrepreneurship literature and universities, specifically among the emerging economies. The preliminary findings allow both researchers and universities to identify determinants of social entre- preneurial intention among undergraduates who will one day become the leaders of the country and are expected to contribute effectively to sustainable economic and social development.

\section{Theoretical Implications}

This study provides empirical findings of the proposed model which integrates the Entrepreneurial Event Model by Shapero and Sokol (1982) and Entrepreneurial Potential Model by Kruger and Brazeal (1994) on social entrepreneurial intention among undergraduates in an emerging economy perspective. Various propositions have been put forth by earlier researchers; however, little empirical data were evident. This study serves as one of the earliest studies examining empathy and exposure as antecedents to perceived desirability and perceived feasibility, which in turn affect social entrepreneurial intention. The full mediating effects of perceived desirability on perceived feasibility-intention relationship and perceived feasibility on empathy-perceived desirability relationship enrich the explanation of social entrepreneurial intention literature. 


\section{Practical Implications}

The perception of feasibility of setting a social enterprise does not directly affect the social entrepreneurial intention per se, rather, when perceived feasibility is high, the perception of desirability will be greater, which in turn, leads to more positive social entrepreneurial intention. This finding implies that the university should focus on activities to cultivate the desirability perception among undergraduates in order to promote more social entrepreneurial start-ups. Meanwhile, perceived feasibility of social enterprise is found to mediate relationship between empathy and perceived desirability. The finding implies that it could be more difficult to foster empathy among undergraduates, it is more practical to expose students to the feasibility of social enterprises in the country, which will indirectly enhance the social entrepreneurial intention. As such, social entrepreneurship course is impetus to universities and institutions aiming to stimulate the development of social entrepreneurship in the country.

\section{Limitations and}

\section{Recommendations for Future Research}

The study adopted cross-sectional design where causal relationship is difficult to be established. Future research on the social entrepreneurship may employ longitudinal design in order to establish causal and probable reciprocal relationships among the constructs. The samples collected through quota sampling procedure limit the generalizability of the findings. In addition, the sample size of 257 is considered small compared with the business undergraduate population in Malaysia. Future research may concentrate on the feedback from entrepreneurship undergraduates or compare students from different streams of studies. The low variance explained by the model indicates that other factors may better explain the social entrepreneurial intention among business undergraduates in the emerging economies. It is recommended that future studies examine contextual factors, for instance, the university's entrepreneurial climate, vision and mission, and role of lecturers in promoting social entrepreneurial activities in the university. Even though behavioral intention has been found to be correlated with actual behavior in many prior empirical studies concerning the establishment of business enterprises, the social entrepreneurial intention may not have a similar impact. As such, the actual setup of social enterprises will better reflect the growth and development of social entrepreneurship in the country.

As one of the earliest studies examining the antecedents to social entrepreneurial intention among business undergraduates in an emerging economy, this study provides preliminary findings on the roles of empathy, exposure, perceived desirability, and perceived feasibility on social entrepreneurial intention. It is hoped that more research will be conducted to add richer information and contribute to the literature in the field of social entrepreneurship, specifically in the context of emerging economies. 


\section{References}

Ajzen, I. 1991. The theory of planned behavior. Organizational Behavior and Human Decision Processes 50: 179211.

Bandura, A., C. Barbaranelli, G. V. Caprara, and C. Pastorelli. 2001. Self-efficacy beliefs as shapers of children's aspirations and career trajectories. Child Development 72 (1): 187-206.

Baron, R. M., and D. A. Kenny. 1986. The moderator-mediator variable distinction in social psychological research: Conceptual, strategic, and statistical considerations. Journal of Personality and Social Psychology 51: 1173-1182.

Basu, A., and M. Virick. 2008. Assessing entrepreneurial intentions amongst students: A Comparative study. Paper presented at the National Collegiate Inventors and Innovators Alliance Conference.

Bernama. 2010. Varsities Urged to Pioneer Social Entrepreneurship. Retrieved January 2, 2013, from http:// malaysiatop1000.com/portal/category/tags/social-entrepreneurship

Bird, B. 1988. Implementing entrepreneurial ideas: The case for intention. Academy of Management Review 13 (3): 442-453.

Brock, D. D., and S. Steiner. 2009. Social Entrepreneurship Education: Is It Achieving the Desired Aims? Retrieved from http://ssrn.com/abstract=1344419

Brouard, F., and S. Larivet. 2010. Social Entrepreneurs: Definitions and Boundaries. ANSER-ARES 2010 Conference, Association for Nonprofit and Social Economic Research (ANSER)/Association de recherche sur les organismes sans but lucratif et l'économie sociale (ARES), Montréal, Canada, June $2-4$.

Carr, J. C., and J. M. Sequeira. 2007. Prior family business exposure as intergenerational influence and entrepreneurial intent: A theory of planned behavior approach. Journal of Business Research 60: 10901098.

Chen, C., R. Green, and A. Crick. 1998. The self-efficacy expectations and occupational

preferences of females and males. Journal of Business Venturing 13 (4): 295-316.

Davis, M. H. 1983. Measuring individual differences in empathy: Evidence for a multidimensional approach. Journal of Personality and Social Psychology 44: 113- 126.

Decety, J., and P. L. Jackson. 2004. The functional architecture of human empathy. Behavioral and Cognitive Neuroscience Reviews 3 (2): 71-100.

Dorado, S. 2006. Social entrepreneurial ventures: Different values so different process of creations, no? Journal of Developmental Entrepreneurship 11:319-343.

Fishbein, M. A., and I. Ajzen. 1975. Belief, Attitude, Intention and Behavior: An Introduction to Theory and Research. Reading, MA: Addison Wesley.

Ghulam, N., H. Rick, and W. Andreas. 2010. Entrepreneurial intentions among students: Towards a refocused research agenda. Journal of Small Business and Enterprise Development 17 (4): 537-551.

Ismail, M., S. A. Khalid, M. Othman, K. Jusoff, N. A. Rahman, K. M. Kassim, and R. S. Zain. 2009. Entrepreneurial intention among Malaysian undergraduates. International Journal of Business and Management 4 (10): 54-60.

Keat, O. Y., C. Selvarajah, and D. Meyer. 2011. Inclination towards entrepreneurship among university students: An empirical study of Malaysian university students. International Journal of Business and Social Science 2 (4): 206-220. 
Krueger, N. F., and D. V. Brazeal. 1994. Entrepreneurial potential and potential entrepreneurs. Entrepreneurship Theory and Practice 18 (3): 91-104.

Krueger, N. F. 1993. The impact of prior entrepreneurial exposure on perceptions of new venture feasibility and desirability. Retrieved January 5, 2013, from http://findarticles.com/p/articles/mi_hb6648/is_n1_v18/ ai_n28633056/?tag= content;col1

Krueger, N. F., M. D. Reilly, and A. L. Carsrud. 2000. Competing models of entrepreneurial intentions. Journal of Business Venturing 15: 411-432.

Kuehn, K. W. 2008. Entrepreneurial intentions research: Implications for entrepreneurship education. Journal of Entrepreneurship Education 11: 87-99.

Mair, J., and E. Noboa. 2003. Social entrepreneurship: How intentions to create a social enterprise get formed. Working Paper 521. IESE Business School-University of Navarra: Barcelona.

McDonald, N. M., and D. S. Messinger. 2010. The Development of Empathy: How, When, and Why. Department of Psychology, University of Miami: USA. Retrieved January 8, 2013, from http:// www.psy.miami.edu/faculty/dmessinger/c_c/rsrcs/rdgs/emot/McDonaldMessinger_Empathy\%20Development.pdf.

Mitchell, R., L. Busenitz, T. Lant, P. McDougall, F. Morse, and J. Smith. 2002. Toward a theory of entrepreneurial cognition. Entrepreneurship Theory and Practice 26: 93-104.

Nabi, G., R. Holden, and A. Walmsley. 2010. Entrepreneurial intentions among students: Towards a refocused research agenda. Journal of Small Business and Enterprise Development 17 (4): 537-551.

Ooi, Y., K., S. Christopher, and M. Denny. 2011. Inclination towards entrepreneurship among university students: An empirical study of Malaysian university students. International Journal of Business and Social Science 2 (4): 206-220.

Pearce, J., and J. P. Doh. 2005. The high impact of collaborative social initiatives. MIT Sloan Management Review 46: 329-339.

Peterman, N. E., and J. Kennedy. 2003. Enterprise education: Influencing students' perceptions of entrepreneurship. Entrepreneurship Theory and Practice 28 (2): 129-144.

Prabhu, G. N. 1999. Social entrepreneurial leadership. Career Development International 4 (3): 140-145.

Prieto, L. C. 2010. The influence of proactive personality on social entrepreneurial intentions among African American and Hispanic undergraduate students: The moderating role of hope. Unpublished Doctoral Dissertation. Louisiana State University and Agricultural and Mechanical College.

Sabrie, M. S. 2010. Entrepreneurship Survey among Malaysian Youths. Retrieved December 24, 2012, from http://mentproject.wordpress.com

Scheiber, L. 2012. Social entrepreneurs in Rio de Janeiro: Learning experiences and social capital. Unpublished Doctoral Dissertation. Retrieved November 12, 2012 from http:// academiccommons.columbia.edu/catalog/ac:146422

Shaker, A. Z., G. Eric, O. N. Donald and M. S. Joel. 2009. A typology of social entrepreneurs: Motives, search processes and ethical challenges. Journal of Business Venturing 24 (5): 519-532.

Shapero, A., and L. Sokol. 1982. The social dimensions of entrepreneurship. In C. Kent, D. Sexton and K. Vesper (Eds.), Encyclopaedia of Entrepreneurship: 72-90.

Shook, C. L., R. L. Priem, and J. E. McGee. 2003. Venture creation and the enterprising individual: A review and synthesis. Journal of Management 29 (3): 379-399. 
Singh, I., T. Prasad, and R. D. Raut. 2012. Entrepreneurial intent - A review of literature. Proceedings of the Ninth AIMS International Conference on Management. Maharashtra, India.

Smith, A. 2006. Cognitive empathy and emotional empathy in human behavior and evolution. The Psychological Record 56: 3-21.

Sobel, M. E. 1982. A symptotic confidence intervals for indirect effects in structural equation models. In S. Leinhart (Ed.), Sociological Methodology: 290-312. San Francisco: Jossey-Bass.

Spear, R. 2006. Social entrepreneurship: A different model? International Journal of Social Economics 33 (5/ 6): 399-410.

Stueber, K. 2008. Empathy. In E. N. Zalta (Ed.), The Stanford Encyclopedia of Pbilosophy (Fall ed.). Retrieved from http://plato.stanford.edu/archives/fall2008/entries/empathy/

Tenth Malaysia Plan. 2010. Tenth Malaysia Plan 2011-2015. Speech presented by the Prime Minister introducing the motion to table the Tenth Malaysia Plan at the Dewan Rakyat, Malaysia. Retrieved December 3, 2012, from: http://www.epu.gov.my/html/themes/epu/html/.../img/ pdf/.../foreword.pdf

Thompson, E. R. 2009. Individual entrepreneurial intent: Construct clarification and development of an internationally reliable metric. Entrepreneurship Theory and Practice 33 (3): 669-94.

Tukamushaba, E. K., L. Orobia, and B. P. George. 2011. Development of a conceptual model to understand international social entrepreneurship and its application in the Ugandan context. Journal of International Entrepreneurship 9: 282-298.

Zahariah, M. Z., M. A. Amalina, and K. G. Erlane. 2010. Entrepreneurship intention among Malaysian business students. Canadian Social Science 6 (3): 34-44.

Zajonc, R. B. 1968. Attitudinal effects of mere exposure. Journal of Personality and Social Psychology 9 (2): 1-27. 
